\title{
MORE ON PASSING ON: A REPLY TO-COOTER AND TO VITON AND WINSTON
}

\author{
ROBERT G. HARRIS $†$ \\ AND \\ Lawrence A. Sullivan +
}

The essays by Cooter ${ }^{1}$ and by Viton and Winston ${ }^{2}$ criticize and elaborate on aspects of our Article published previously in this Review. ${ }^{3}$ Both essays contain interesting points that are technically correct. Neither warrants any substantive change in our analysis of passing on, in our policy conclusions, or in the techniques for adjudicating passing-on issues described in our Article:

\section{Reply to Professor Cooter}

In any situation in which passing on would be an issue, the direct purchaser is, by economic definition, buying a "factor input," not a "final product." Because of this, Professor Cooter argues, both the Supreme Court's decision in Illinois Brick Co. v. Illinois." and our Article were incorrect in using a version of tax incidence theory that does not account directly for factor substitution to estimate the extent of passing on. But given our goal of developing a workable policy for litigation in markets in which significant monopoly overcharges are actually encountered, the scant attention paid to factor substitution is all that the topic deserves. For two reasons, we remain convinced that " $[t]$ he possibility of significant factor substitution by [direct purchasers] . . implies an elastic demand curve between [the manufacturer and direct purchasers] .... in which case monopolistic pricing is highly improbable. Hence, it is reasonable to assume that factor substitution is relatively low in passing-on cases." 8

f Assistant Professor of Business Administration, University of California, Berkeley. B.A. 1965, M.A. 1973, Michigan State University; Ph.D. 1977, University of California, Berkeley.

tf Earl Warren Professor of Public Law, University of California, Berkeley. A.B. 1848, University of California, Los Angeles; J.D. 1951, Harvard University. 1 Cooter, Passing on the Monopoly Overcharge: A Further Comment on Economic Theory, 129 U. PA. L. Rev. 1523 (1881).

2 Viton \& Winston, Passing on the Monopoly Overcharge: The Welfare Implications, 129 U. PA. L. REv. 1516 (1981).

3 Harris \& Sullivan, Passing on the Monopoly Overcharge: A Comprehensive Policy Analysis, 128 U. PA. L. REv. 269 (1979).

4431 U.S. 720 (1977).

6 Harris \& Sullivan, supra note 3, at 292 n.59. 
The first reason factor substitution is less significant than Professor Cooter argues concerns the way managerial decisions are made. Cooter employs a version of neoclassical production theory that assumes: (1) that manufacturers face an infinite array of choices regarding the combination of inputs in producing any particular output; (2) that manufacturers have constant and costless access to all information about all these alternatives, and (3) that managers constantly minimize production costs by extremely fine and continuous adjustments of factor inputs as relative factor prices change. ${ }^{B}$ If these assumptions were accurate, factor substitution would costlessly and effortlessly occur as soon as a monopolist or a cartel raised prices. Thus, not only would the passing-on problem be greatly diminished, but also the problem of monopoly overcharges itself would be much alleviated.

Professor Cooter's assumptions about managerial behavior, however, do not conform to reality. Herbert Simon's behaviorial model of the firm is much closer to the truth (though admittedly less susceptible to elegant mathematical techniques). ${ }^{7}$ Managers may well face a vast array of possible combinations of inputs. But they are constrained by limited time, limited information, limited energy, and limited mental capacity. Consequently, they are limited-and deliberately limit themselves-in their range of choices. Input combinations are seldom reinvestigated, let alone changed, unless some substantial perturbation thrusts the input question onto the agenda for managerial attention. Even then, managers gather and evaluate only information that is reasonably accessible. Moreover, there is always inertial pressure against making any change that will alter purchasing relationships unless the change promises a substantial cost reduction that appears likely to continue for a significant period of time.

The second reason that input substitution is less significant than Professor Cooter presumes concerns technological limitations. ${ }^{8}$ In his analysis, Cooter compares his model of perfect substitutability to only the most restrictive example of limited factor substitutability-namely, fixed factor proportions (when there is one, and only one, technologically feasible proportion of inputs). More complex, and probably more frequent, are the intermediate cases in which

'These assumptions are embodied in the smooth, curved line in Cooter's Figure 4. See Cooter, stipra note 1 , at 1528 .

7 See Harris \& Sullivan, supra note 3, at 299-303, 301 n.70.

8 Indeed, although technological limitations on factor substitution are logically separable from limitations rooted in managerial behavior, the two are not mutually exclusive. Technological limitations may bound a zone within which managers do not consider changing input factor proportions. 
some substitutability, but not an unlimited amount, is possible. As shown in our Figure 1, this condition of limited substitutability is not represented by a smooth curve like that in Professor Cooter's Figure 4, but has "kinks" (that is, the curve is not continuously differentiable). ${ }^{9}$

\section{FIGURE 1}

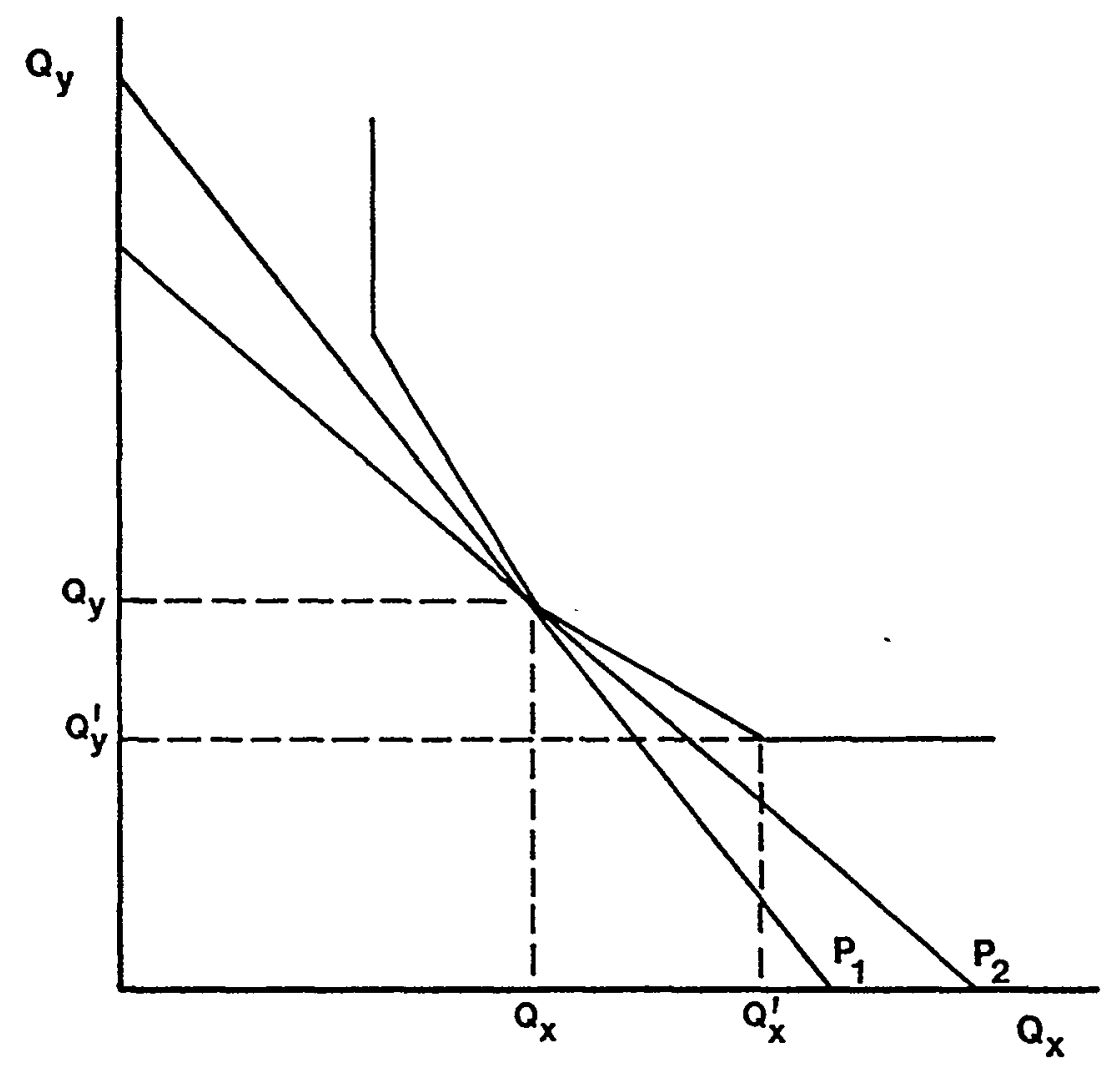

In these circumstances, small changes in relative factor prices might have no effect on the least-cost factor proportions. If, for example, the relative prices of factors $X$ and $Y$ were those presented by the price $P_{1}$, then the cost-minimizing factor proportion is represented by the intersection $Q_{x}, Q_{y^{*}}$. Suppose now that the producers of factor $\mathrm{Y}$ cartelize and increase their price to a supracompetitive level-this price shift is represented by price line $\mathrm{P}_{2}$. Nevertheless, $Q_{x}, Q_{y}$ remains the cost-minimizing combination of inputs. Only a very large shift in the relative prices of $X$ and $Y$ would make it

O For a complete economic analysis of production theory, see W. BAOMor, Economic Theony and Operations ANALYsis (4th ed. 1977) (especially ch. 12). 
rational for the firm to change its factor proportions (to, say $\left.Q_{x}^{\prime}, Q_{y}^{\prime}\right)$. Thus, small price changes have no effect on factor proportions, whereas a substantial change in relative prices can have a correspondingly large effect on the quantity of $X$ and $Y$ purchased.

This analysis brings us to the point made in our Article and the reason why factor substitutability was relegated to a footnote. ${ }^{10}$ Given both the behavioral limits of managerial decisionmaking and the technological limits on factor substitutability, only a significant change in relative factor prices is likely to induce factor substitution. But potential price fixers (or other overchargers) are as likely, or more likely, than are their customers to have information about these limits. In these circumstances, as noted in our original footnote, price fixers are not likely to raise prices to the point at which they would suffer large output losses owing to factor substitution by direct purchasers. ${ }^{11}$

We do not suggest that factor substitutability should be ignored in passing-on litigation. As Professor Cooter suggests, it would be a relatively straightforward exercise for a court to determine whether a significant degree of factor substitution had actually occurred. If it had, the burden imposed on final consumers would be reduced. But even then (as Professor Cooter agrees) the final consumers-not the direct purchasers-would bear the burden. Thus, Professor Cooter's essay impeaches neither our assertion that indirect purchasers should have the opportunity to prove and recover their losses nor the method we described for determining what portion of the total overcharge is allocable to purchasers at each vertical stage.

\section{Reply to Professors Viton and Winston}

Although our Article extends and supplements price theory with behavioral and institutional considerations, it is nonetheless true, as Professors Viton and Winston say, that our analysis is "partial." We assumed that courts hearing passing-on cases would examine only one vertical distribution chain and would ignore possible imperfections in related markets. We did not assume that a

10 See Harris \& Sullivan, supra note 3, at 292 n.59.

11 To confirm our claim that factor substitutability is not frequently an important issue, we reviewed the economic facts in the sixty-five recent price fixing cases summarized in the Appendix accompanying our Article. Id. 355-60. Although lacking in the information needed to make precise determinations, it is readily apparent that factor substitutability would have occurred in very few of these cases. Further, we are of the opinion that factor substitutability was unimportant or nonexistent in all of the twenty-eight cases in which we ascribed the rate of passing on as "high." 
court in an antitrust case should try to deal with the whole economy or any larger portion of it than the market in which the challenged trade restraint applies. 12

If one assumes that all markets in the economy, save one, are either perfectly competitive or subject only to mutually offsetting distortions, Professors Viton and Winston are correct in noting that imposition of an "overcharge" in one of the competitive markets might actually improve allocative efficiency (that is, "welfare," as they use that term) because the newly imposed overcharge might "correct" for the defect in the one noncompetitive market. Given the interdependence of markets, one can picture a situation in which two "wrongs" might make a "right," or might at least be better than one "wrong." In the specific example offered by Professors Viton and Winston, that of unregulated trucking versus regulated railroad service, if all other markets are assumed to be competitive, allocative efficiency might be improved by motor carrier prices in excess of marginal costs. ${ }^{13}$

It is a considerable leap, however, to argue from that single two-market example, that the Illinois Brick decision might as a rule (that is, over a number of cases), produce results that are economically superior to the results implied by our analysis. There are two main reasons why we challenge that position.

First, there is a matter of economics: If one accepts the restrictive, value-laden assumptions embodied in neoclassical theory (or, for that matter, in any system of economic thought), it is possible to logically prove certain results. For example, if one assumes, inter alia, that the prices of all other products are equal to their marginal social cost of production, one can prove that allocative efficiency would be increased if the price of the product under analysis were also equal to its marginal social cost of production. If the assumption about the prices of other products were not true (and, of course, those required assumptions never are true), economic theory simply cannot prove at what price the analyzed prod-

12 There is a long tradition of "general analysis" in theoretical economics which, purportedly, incorporates all economic action and activities simultaneously. Analysis of this kind requires an extraordinarily high level of abstraction and highly restrictive assumptions regarding the technical and behavioral characteristics of an economy. Consequently, it is seldom used in policy related analyses. The law characteristically deals in particularities and mid-level generalizations and rarely, if ever, attempts a sweeping, general analysis of economic or equity issues. So far as we are aware, no antitrust court has ever attempted a general analysis.

18 A similar problem of "second-best"-involving the same two industries-was emphasized in an analysis of railroad regulatory policy toward branch line abandonments. See R. Harris, Simple Analytics of Rail Costs and Disinvestment Criteria, Transportation Research Record No. 687, at 19 (1978). 
uct must sell to maximize allocative efficiency. This is known as the problem of "second best," and the thrust of the Viton-Winston essay is that we have ignored it.

Far from ignoring the second-best dilemma, each of us has elsewhere cited it as a major reason why policy cannot be based solely on, and why caution is essential regarding the results of, economic theory. ${ }^{14}$ Our disagreement with Professors Viton and Winston does not concern the existence of the dilemma, but rather what to do about it. They treat allocative efficiency-a general equilibrium condition-as the sole goal of antitrust law. Yet, they apparently think second-best problems can be solved by looking only at one or two markets adjacent to that in which an antitrust restraint arises. If those markets are all competitive, presumably Viton and Winston would have the court apply antitrust principles to try to make the restrained market more competitive, assuming that this would bring the economy as a whole closer to allocative efficiency. In such an instance, we infer, they would allow indirect purchasers to sue for monopoly overcharges. If, however, one or more adjacent markets is not competitive, Professors Viton and Winston presumably would have the court countenance monopolization or cartelization in the restrained market. ${ }^{15}$

We are persuaded, by contrast, that second-best problems actually make it infeasible to use allocative efficiency as the basic goal of antitrust policy.16 The second-best problem is not the danger that an antitrust correction in one market is likely to yield a global loss in allocative efficiency. The problem, rather, is that there exists no theoretical or empirical basis for drawing any inference about what effect a correction in one market will have on allocative efficiency. An antitrust action may result in a closer relationship between price and costs in a particular market. But if one specifies allocative efficiency as the sole goal of antitrust (as Viton and Winston implicitly do), one must judge every antitrust law suit by asking whether it moves the entire economy closer to

14 See, e.g., L. Sul.rvan, Handbook of the LAw of Antrtrust 2-7 (1977); Harris, Deregulation: Panacea or Reform, Working Paper of the Center for Transportation Policy and Research, Berkeley (presented to Midwest Economic Association in 1980) (on file with author).

15 The implication of their essay is that in such circumstances indirect purchasers should not have a damage action to recover the amount of an overcharge passed on to them. They do not make clear whether they would allow a damage action to the direct purchaser, or would allow the government to enjoin or criminally punish the violation. The logic of their position would appear to preclude any enforcement against cartelists in cases in which adjacent markets are not competitive.

16 See note 14 supra. 
that highly particularized condition of system-wide equilibrium. An answer to that question will never be available.

A single market correction would move in the direction of improving system-wide allocative efficiency only if: (1) all other markets could be held unchanged while one was corrected (a theoretical impossibility); or (2) the ramifications of the correction in the single market could be traced sufficiently far to warrant a confident judgment that, on balance, the system-wide effect was in the correct direction (an empirical improbability). Candid and realistic practitioners of both law and economics must concede that the day when courts and juries will be capable of doing or comprehending analyses so complex and far reaching is a long way off. For that matter, we are still a good distance from the day when economic theorists are able to carry out such an analysis in a rigorous manner. Certainly, Professors Viton and Winston have not done it in their hypothetical two-market example. Simply noting that the ultimate system-wide impacts of any given correction turn on the strength of interdependence does not put us in possession of the analytic technology that would enable us to use antitrust to move the economy, as a whole, closer to a state of allocatively efficient equilibrium.

Consequently, we take issue with Professors Viton and Winston's implication that allocative efficiency is the sole measure for comparing antitrust policies. Our reading of legal history suggests that "dread of enhancement of prices," 17 a concern about shifting income from consumers to monopolists and cartelists, not allocative efficiency, is the basic economic goal of antitrust. ${ }^{18}$ This, unlike allocative efficiency, is a goal that does not depend on economy-wide effects and that can be advanced in one market at a time. ${ }^{18}$

17 See Standard Oil Co. v. United States, 221 U.S. 1 (1911).

18 See L. SULIrvaN, supra note 14, at 2-8.

19 But see Williamson, Assessing Vertical Market Restrictions, 128 U. PA. L. REv. 953, 985-88 (1979), which also criticized the view that we are expressing here. Without making any attempt to show that it would be feasible to do a general analysis in an antitrust case, Williamson appears to rely on the theoretically and empirically unfounded assumption that any improvement in price-cost relationships in a single market will tend to improve allocative efficiency economy-wide. In effect, Williamson shifts the burden of proof and challenges those who think second-best problems may seriously interfere with the prospect of increasing allocative efficiency through antitrust to prove him wrong. Because both Williamson and we start by supporting antitrust enforcement in any market in which a restraint reduces output, it may appear that there is no practical difference between his view and ours. The logic of Williamson's position, however, would require that he back away from antitrust enforcement on facts like those in the Viton-Winston transportation market hypothetical, where the evidence, so far as traced, suggests that allocative efficiency is not being served. Because we identify the goal of the law as foreclosing wealth 
By emphasizing the "welfare triangle" in their Figure $1{ }^{20}$ (a graphical measure of the "deadweight" loss due to allocative inefficiency), Professors Viton and Winston fail to acknowledge the distributional consequences of their hypothetical mark-up of motor carrier price above marginal cost. Their own graph shows-but they fail to mention-an income transfer from the users to the producers of motor carrier services in an amount equal to the rectangle to the left of triangle $B$. This "distributional rectangle" is nevertheless-in their example and in virtually all real cases-considerably larger than the "efficiency triangle." Professors Viton and Winston, like most economists, ignore it. Antitrust law, and our analysis, does not.

transfers from consumers to monopolists or cartelists, we support enforcement in all instances in which output is restricted by supracompetitive pricing.

20 Viton \& Winston, supra note 2, at 1520. 